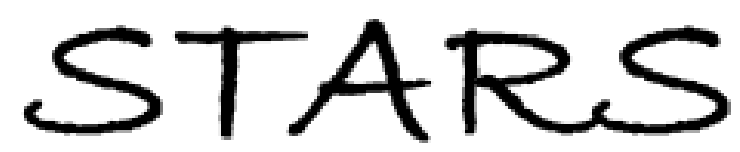

University of Central Florida

STARS

$5-1-2008$

\title{
Spatial Dimensions of the Orlando Destination Region
}

Shaul Krakover

Youcheng Wang

University of Central Florida, Youcheng.Wang@ucf.edu

Part of the Hospitality Administration and Management Commons, and the Tourism and Travel Commons

Find similar works at: https://stars.library.ucf.edu/rosenscholar

University of Central Florida Libraries http://library.ucf.edu

This Paper is brought to you for free and open access by the Rosen College of Hospitality Management at STARS. It has been accepted for inclusion in Rosen Faculty Scholarship and Creative Works by an authorized administrator of STARS. For more information, please contact STARS@ucf.edu.

Original Citation

Krakover, S., and Wang, Y. C. (2008). Spatial Dimensions of the Orlando Destination Region. Tourism Analysis, 13(3), 245-258.

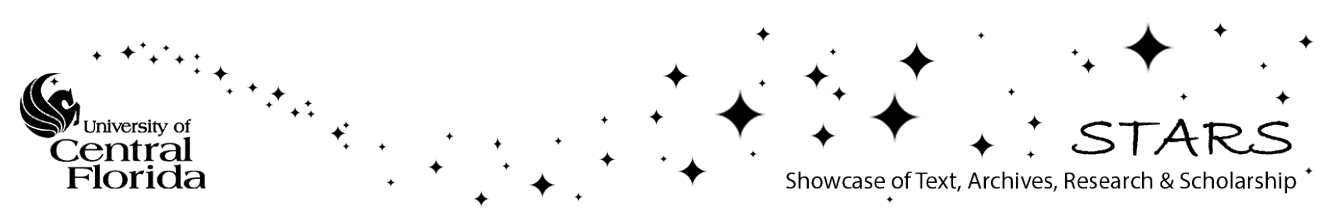




\title{
SPATIAL DIMENSIONS OF THE ORLANDO DESTINATION REGION
}

\author{
SHAUL KRAKOVER* and YOUCHENG WANG $\dagger$ \\ *Department of Geography and Environmental Development, \\ Ben-Gurion University of the Negev, Beer-Sheva, Israel \\ $\nmid$ Rosen College of Hospitality Management, University of Central Florida, Orlando, FL, USA
}

\begin{abstract}
This article aims to empirically examine the concept of a destination region using a case study approach. Two conflicting hypotheses are considered for the spatial structure of tourism in Orlando's destination region: the bubble pattern vis-à-vis a dispersed pattern. Locational concentration and the industrial mix of Orlando's tourist-related firms are examined by analyzing data revealing their location and business specialization. Findings reveal the concentration of the accommodation and dining firms near the theme parks area in a bubble-like pattern. Conversely, smaller scale attractions, convention services, and visitor and professional services tend to locate in high proportions outside of the core area. Implications are discussed from both theoretical and practical perspectives.
\end{abstract}

Key words: Destination region; Industrial mix; Bubble; Agglomeration;

Convention and visitor bureau

\section{Introduction}

A literature review suggests that tourism researchers have not addressed the issue of destination area boundaries despite their obvious impact on the community's social life. A clear notion of the geographic extent of any destination region has important social and economic repercussions (Heath \& Wall, 1992). First, the geographic extent of the destination region has important implications for the actual operation of destination marketing organizations (DMO). Concerning accountability issues, tourism offices and convention and visitors bureaus (CVB) have to decide which busi- nesses they are representing in their administrative, marketing, and promotion operations. Second, it is of great interest, in most cases, to the duespaying members of these DMOs to know what businesses, including competitors, complementary businesses, or potential alliances, are being promoted on the basis of territorial affiliation. Third, it is important for public officers and tax-paying citizens of the jurisdiction in question to know what their tax money is being used for. Is their money spent for the benefit of the local constituencies or are their services extended freely to the neighboring entities? Last but not least, a successful demarcation of a destination region has serious 
implications for land use, transportation, and town planning considerations (Dredge, 1999; Gunn \& Var, 2002).

This research attempts to empirically examine the concept of a destination region, utilizing the Orlando tourism area as a case study with the aid of locational data related to firms associated with the Orlando/Orange County Convention and Visitor Bureau (OOCCVB). In the American context, CVBs usually fulfill a pivotal role in the tourism industry at the destination level with the primary task of coordinating marketing and promotional activities (Presenza, Sheehan, \& Ritchie, 2005). As a result, CVBs influence the structure of the tourism industry at the destination/community level. Contrary to the clarity involved in defining the CVBs' marketing mission (Gartrell, 1992), their role in forging a geographically coherent destination region still awaits further elaboration.

To achieve its goals this article analyzes the geographic dispersion and industrial mix of the tourism-related firms playing role in the Orlando destination region. Given the lack of previous studies, it is hard to hypothesize with respect to the expected spatial extent of the Orlando tourist destination region. Several scholars suggest that tourism activities tend to be locally concentrated in close vicinity around major attractions, forming a tourist bubble (Judd, 1999; Urry, 1990). JansenVerbeke and Lievois (1999, 2004) suggest using a less value-laden term, "tourist activity space" (TAS), to denote urban nodes of tourism-scapes (tourism landscapes) where tourist supply networks are available to meet tourist demands. The concentration option is also supported by Papatheodorou (2004), who concludes, stating the example of Disney World, that, "concentration is a common feature in both market and spatial evolution of tourism" (p. 226).

Thus, on the one hand, the analysis may yield a high agglomeration of attractions, accommodations, restaurants, and other firms closely located near the major theme parks, so as to take advantage of the externalities involved. On the other hand, the large land areas of the theme parks, the rising cost of land, zoning regulations, and the extremely large volume of tourists may result in a wide dispersal of tourist service providers covering a large area and creating a dispersed destina- tion region. Such deliberation is in line with questions raised in the area of economic geography with respect to the prevalence of agglomeration economies (Krugman, 1998; McCann \& Shefer, 2005). In addition, the identification and delineation of destination regions have the potential of providing implications not only for marketing but also for other issues related to tourism development such as place identity and community sentiment (Christenson, 1993; Sheldon \& Abenoja, 2001). These issues and others will be elaborated on following the investigation of the destination region.

\section{Theoretical Background}

Gunn (1988) presented one of the most thorough works on the spatial dimension of vacation spaces. Taking an architectural designer viewpoint, he conceptualized "vacationspace" as a tripartite unit composed of a nucleus, an inviolate belt, and the zone of closure (pp. 49-50). The nucleus is the main attraction or the heart of the vacationspace. The inviolate belt is the setting or the buffer zone a visitor must pass in order to reach the nucleus. The zone of closure is the surrounding area including one or more service centers and transportation linkages. There is no indication, however, of the actual geographic dimensions this vacationspace is spread over.

Gunn (1988) later replaces vacationspace with the concept of "tourism destination." This concept incorporates attraction clusters, an urban destination zone, and an extended destination zone on an urban-remote scale. The remote segment of this scale consists of suburban, rural, and remote zones suited for low-density tourism activities. Again, no indication is given to the actual geographic size, the composition of the spatial pattern and industrial mix of these zones. The geographic perception of the author is reflected, however, in his visual demonstration where, "hypothetical small destination zones," are portrayed (p. 62). He visualizes the tourism destination concept in the form of concentric zones centered upon a city and appears to reach out to a distance anywhere between 10 and 50 miles.

Gunn and Var (2002) later reinforced the aforementioned wider and all-inclusive scale by defin- 
ing the "destination zone ... as a community (or several) and the surrounding area" (p. 23). This term concurs with "contemporary views of urban development ... combining a central city with its periphery into a single unit" (p. 23). Gunn and Var explicitly relate their tourism destination structure to the distance-decay "regiopolis" model suggested by Gradus and Stern (1980, p. 224). Gunn's ideas may also easily be associated with several classical distance-decay models, such as von Thunen's, "isolated city" (1826/1966) or Walter Christaller's, “central place theory" (1933/1966). Such theoretical deliberations, however, are beyond the scope of this article.

The need to define destination regions for planning purposes has been stressed by several other authors (Dredge, 1999; Fagence, 1991; Getz, 1986; Inskeep, 1991; Jansen-Verbeke, 1992; Pearce, 1995). Nonetheless, most of these authors would probably agree with Dredge (1999) "that despite considerable advancement in the development of methodological processes of tourism planning, there is a lack of spatial concepts, models, and theories from which the land use planner can draw" (p. 773). Dredge suggests a model for a destination region that leans heavily on Gunn's conceptual framework. In her work, Orlando is perceived as an example of "multiple node destination region" (p. 787). Despite the conceptual advancement made by Dredge in terms of the components that build a destination region and the complexity generated by her conceptualization of "multiple nodes" and "chained destination regions" (constructed by connecting either single node and/or multiple nodes), the concept of destination region still awaits its practical demarcation and internal specification.

A search for destination area specification in the prolific literature of TALC (tourism area life cycle) modeling (Butler, 1980, 2006) is perplexing the geographic size of the "tourism area." Some authors apply the model to such small areas as a single attraction (Benedetto \& Bojanic, 1993) while others apply it to as wide an area as cities or islands (Douglas, 1997; Karplus \& Krakover, 2004). While the strength of TALC modeling lies in its evolutionary morphogenesis nature, its weakness rests in the lack of reference to the size of the tourism area, its demarcation, and internal struc- ture, including its industrial mix. Papatheodorou (2004) made an excellent case to reexamine TALC's basic assertions by focusing "on the inherent dynamics of the tourism industry and their territorial expression" (p. 221). However, in his modeling he preferred to treat tourism flows and evolutionary processes on the macro geographic scale rather than the metropolitan scale which is the focus of this article.

\section{CVBs and Their Indefinite Destination Regions}

The role and function of CVBs as DMOs are recurring themes in tourism literature relating destination marketing/management and tourism planning. Morrison, Bruen, and Anderson (1998), following classification of CVBs into four types, conclude that their primary responsibility is to act as DMOs. They have become the principal organizations responsible for marketing destinations to large and small meetings, to pleasure travel groups, and to independent travelers (Weber, 2001). The CVBs' main mandate is to promote visitation in their respective destination areas (Bramwell \& Rawding, 1994). This mandate, however, necessitates an inquiry into the question of what exactly is a destination area, how is it defined, and what is the role that CVBs play in creating coherently perceived destination areas. In addition, much of the literature on CVBs is occupied with the role they play in helping to create business alliances and networks with the purpose of promoting visitation in their destinations (Augustyn \& Knowles, 2000; Fyall \& Garrod, 2004). This partnershipbuilding role is justified by the nature of the tourism industry and the unique characteristics of selling a destination as compared to selling other consumer products (Palmer \& Bejou, 1995). The impact of this collaborative partnership building process, which practically determines the composition of destination regions, is still not definitive in the literature.

A review of literature in this area has revealed that the roles of CVBs in influencing destination regions have been anecdotally examined from different perspectives. In this literature the word "destination" is always present, yet its geographic attributes are seldom defined. For example, Gartrell (1992) argues that CVBs are charged with the 
tasks of developing an image that will position their destinations in the marketplace as a viable destination for meetings and visitors and they must coordinate those constituent elements, which are quite independently diverse. Clearly, the destination's image depends on the composition of these constituent elements and the geographic extent from which they are drawn (Laws, 1995). Another example is the World Tourism Organization (WTO) (2004), which defines CVBs/DMOs as organizations responsible for the management and/ or marketing of destinations. Taking both the geographic as well as administrative levels into consideration, the WTO assigns DMOs on a scale from national, to regional, to local. Yet, no insight has been provided as to the dynamic scope in which these different levels of DMOs operate. The current study attempts to fill a gap in the research regarding the concept of destination regions and the role of DMO in forging the spatial dimension of the destination region.

\section{Research Area, Data Source, and Methodology}

This study takes Orlando as a case of investigation. Orlando has emerged as one of the world's largest tourist destinations over the past three decades. Hudman and Jackson (2003) assert that, "Orlando, Florida, with its variety of theme parks is the number one destination for both international and domestic tourists in the United States" (p. 66). The famous theme parks (e.g., Disney World, Sea World, and Universal Studios) and a multitude of other attractions located in this destination drew a total of more than 49 million visitors in 2005. The number of visitors to Orlando in the last 10 years has grown steadily and appears to overcome the slowdown caused by the $9 / 11$ atrocious terror attacks in 2001. In 2005, visitors contributed US\$28.2 billion in spending to the Orlando metro area (Orlando CVB, 2005).

The development of Orlando into a mega-destination should be attributed, first of all, to the entrepreneurial and marketing skills of the Orlando-based tourism businesses and enterprises, particularly those with strong international and national influence such as the Disney World theme parks, Universal Studios, Sea World, and other lodging conglomerates (Foglesong, 1999). Never- theless, one cannot ignore the role played by DMOs such as Orlando/Orange County Convention and Visitor Bureau (OOCCVB). This is a typical behind-the-scene organization that acts as an intermediary between visitors and their service providers. Its main objective is to promote and generate visitation to the Orlando area for the economic benefits of all (Orlando CVB, 2005). The OOCCVB is a private, not-for-profit corporation whose mission is chartered by Orange County and the City of Orlando. This CVB is among the 10 largest tourism bureaus of its kind in the US with 150 full-time employees and an annual budget of US\$40 million, of which US\$18 million comes from the Orange County accommodation tax.

The promotional goals of the Orlando CVB are performed by acting outward and inward (Getz, Anderson, \& Sheehan, 1998; Presenza, Sheehan, \& Ritchie, 2005). Outward actions are centered upon marketing and publication. These include distributing printed booklets and pamphlets, circulating discount offers, managing a well-developed and daily maintained website (Myung, Morrison, \& Taylor, 2005), carrying out advertising campaigns, and keeping contacts with seven internationally based marketing representatives. The CVB website, as a major marketing vehicle, enjoys 3.5 million unique annual sessions, making the website one of the most effective tools for business exposure (Orlando CVB, 2005). This type of promotional activity caters mainly to dues-paying members who rely heavily on CVBs to promote and improve their businesses.

Inwardly, the CVB acts as an information broker and liaison. The information broker function is fulfilled by circulating among its member firms the many requests for reservations and events funneled through the CVB (Migdal, 1993; Ovechka, 1993). The liaison function is played via monthly luncheon meetings, networking, and circulation of research, forecasts, and a general newsletter. These activities benefit mainly those members who are striving for building and enhancing relationships with other businesses in the destination, especially those complementing their own.

The classification of the 1,350 member firms listed in the OOCCVB database for 2005 is presented in Table 1. Five of the seven groups appearing in Table 1 are involved mainly in business- 
Table 1

Orlando CVB membership by Type of Business

Activity: 2005

\begin{tabular}{lcc}
\hline Type of Business & No. of Firms & Percent \\
\hline Accomondation & 317 & 23.5 \\
Convention services & 292 & 21.6 \\
Dining & 244 & 18.1 \\
Visitor \& professional services & 199 & 14.7 \\
Attractions & 184 & 13.6 \\
Retail & 61 & 4.5 \\
Transportation & 53 & 3.9 \\
Total & 1,350 & 100.0 \\
\hline
\end{tabular}

Source: Data provided by the Orlando CVB.

to-customer operations and only two are typical business-to-business service providers. While six of the seven groups are accepted as members regardless of their actual location, membership of firms engaged in the provision of accommodation is geographically bounded. This is mainly because the CVB's budget is partially originated in the accommodation tax levied by Orange County. Accordingly, members in the accommodation sector are concentrated predominantly in five counties in the vicinity of Orlando: Orange, Osceola, Seminole, Lake, and Polk, all but Polk being part of the Orlando Metropolitan Area (OMA) as defined by the US Bureau of the Census as of 1990. Due to the accommodation tax transferred by Orange County to the CVB, Orange County's accommodation firms are entitled to a free membership with the CVB.

The definition of the geographic area designated for marketing by the Orlando CVB is somewhat blurred. Although accommodation taxes are forwarded by Orange County only, and despite its official name-Orlando/Orange County Convention \& Visitors Bureau-its promotional zone as well as its membership distribution covers a much wider area. Thus, when the Orlando CVB states that its goal is "promoting the area" a question arises with respect to the boundaries of the destination area designated for promotion. Examination of the geographic dispersion of other metropolitan size destination areas, such as Toronto, Canada, and Auckland, New Zealand, reveals that the problem of tourism area boundary delineation is not unique to Orlando but may be shared by many other locations.
Research into the geographic dispersion of the area designated for tourism marketing in metroscale regions is at the heart of this study. Data sets on tourism-related businesses are not readily available, let alone their geographic association with a central destination such as Orlando. Thus, the study's objective to examine the Orlando destination area will be achieved by analyzing the distribution of the firms having active membership with the Orlando CVB and enjoying the alliances and benefits accrued by being a part of this organization (Palmer \& Bejou, 1995). Specifically, answers will be sought to the following questions:

1. Are remote memberships expected due to the ample tourism business opportunities and the huge amount of tourist expenditure circulated in this area? If so, to what extent does membership distribution go beyond OMA into Central Florida and beyond?

2. What is the distance decay pattern of the businesses associated with Orlando's CVB? Is it widely dispersed or rather locally concentrated as suggested by the tourist bubble literature?

3 . If there are several concentric zones around Orlando, as suggested by Gunn (1988, 2002), what kind of industrial mix of tourism-related business is typical to each of these zones?

The data source, obtained from the Orlando CVB, consists of 1,350 tourism business establishments having membership with this organization as of the end of 2005. These establishments are classified by the CVB into the seven groups presented in Table 1. Although this database is suitable for the objective of this study-delineation of a functional area where all units are related to a focal point-it does not necessarily supply complete coverage.

According to an assessment provided by the Orlando CVB, their membership covers almost all businesses classified as attractions, convention services, visitor \& professional services (VPS; these include services such as travel agencies, marketing, advertising, and ticket offices), and about $80 \%$ of the accommodation establishments. Common to all of these types of businesses is their dedication to the tourism industry. The other three typesretail, transportation, and dining — serve visitors to 
Orlando as well as the local public. Thus, smaller percentages of these types of businesses are enrolled as members with the OOCCVB. However, businesses enrolled constitute a large sample of the firms having interest in being associated and having alliances with the Orlando tourism business milieu. These firms undoubtedly have stronger business relationships with the tourism industry than others.

The actual addresses of all members of the OOCCVB were provided in the database in detail. In the geographic analysis that follows, the data were aggregated by zip code (ZC) areas. This geographic subdivision was found to be the most appropriate level for the analysis due to the fine mesh of small geographic areas available for the OMA.

It would have been desired to have a clear notion on the exact percentages of tourism firms enlisted in the membership file of the OOCCVB in each ZC area for each specific sector of tourism included in this study. However, this would require a metro-wide business survey, which is beyond the scope of this research. The 1,350 firms enrolled as members with the OOCCVB constitute a large sample of businesses having interest in the opportunities provided by the brand name of the city or other major players in the local arena. They represent the firms having interest of being associated with Orlando as their focal point. It should be noted that the multiplicity of organizations that make up the destination, the complexity of the relationships that exist between them, and the intensification of the complexity due to the tendency for a large number of different stakeholders to be involved are such that tourist destinations are widely acknowledged as entities difficult to define and delineate (Sautter \& Leisen, 1999). Given these difficulties, the OOCCVB database is considered as most appropriate for the delineation of the extent of the local tourism destination area and the study of its territorial and industrial structure.

\section{Data Analysis and Results}

The data analysis is provided in two sections. First, the geographic dispersion of the OOCCVB member firms is presented and displayed; second, the spatial variations in the industrial mix of these firms are analyzed in accordance with the findings related to the geographic subdivisions.

\section{Geographic Dispersion}

Examination of the addresses of the business establishments enlisted in the database reveals that firms taking membership with the OOCCVB are dispersed far beyond the State of Florida. Of the 1,350 members, 75 establishments $(5.9 \%)$ have out of state addresses (Fig. 1). These firms are dispersed among 30 other states, among them: 11 in Texas, 7 in California, 6 in neighboring Georgia, and 2 located as far as Puerto Rico and Winnipeg, Canada.

Members having Florida zip codes (ZCs) were further classified into several geographic units. Almost $91 \%$ of the 1,275 in-state members providing $\mathrm{ZCs}$ are located within the conventionally defined tri-county area of metropolitan Orlando consisting of Orange, Osceola, and Seminole counties (Fig. 1). A small geographically distinct group of 44 members (about 3.5\%) are located in three neighboring counties (Polk, Lake, and Volusia) within a 10-mile zone away from the tri-county boundaries. As a cautionary measure, in order not to err in underestimating the geographic extent of the Orlando destination region, the region will be analyzed with and without this group of members. When this group of member firms is included in the analysis, the region will be defined as the extended tri-county area. Finally, a group of 73 (about 6.1\%) members is dispersed well beyond this 10-mile zone all over the State of Florida including Miami, Tampa, and Tallahassee. Thus, $89 \%$ of all firms or $94.3 \%$ of the in-state firms are concentrated in and near the tri-county area. These percentages attest that firms having interest in becoming members of the OOCCVB are rather concentrated to a large extent within the Orlando metro area and its adjacent hinterland. Only 148 member firms $(11 \%)$ are located outside of this extended Orlando tri-county destination area but still show interest in the business opportunities prevailing in this world-class tourism destination.

Further geographic subdivision is portrayed in Figure 2 by presenting the intra-metropolitan distribution of the 1,202 firms located in the extended Orlando tri-county area. The single largest concen- 


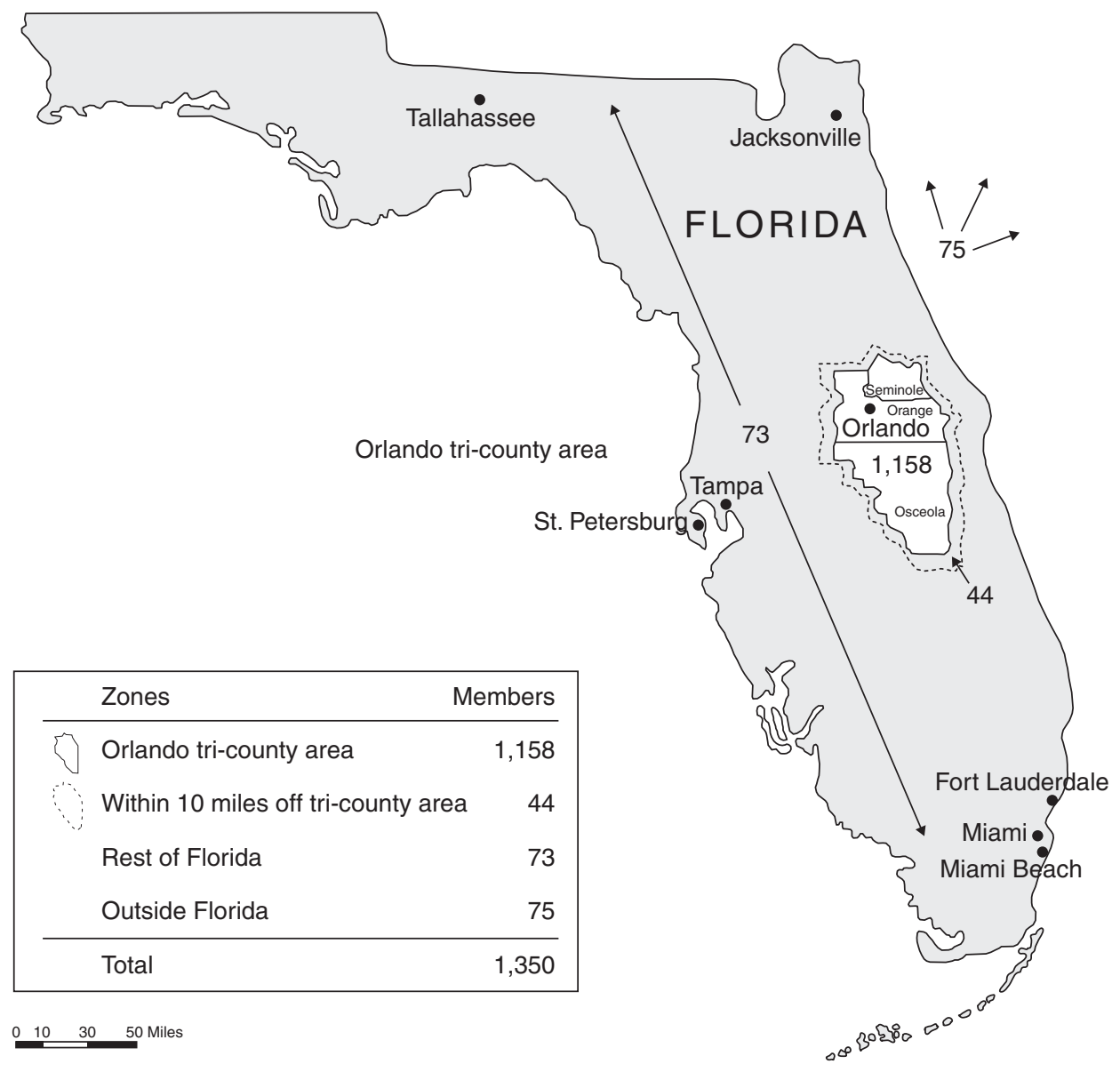

Figure 1. Distribution of firms having membership with the Orlando CVB.

tration of tourism-related firms is clustered near the theme parks area with 713 tourism establishments located in a cluster of nine $\mathrm{ZC}$ areas, each having at least 30 firms. The second largest concentration of this kind is located at the Orlando Central Business District (CBD) area with 87 firms located in two adjacent $\mathrm{ZC}$ areas. The rest of the firms in the extended tri-county area are rather dispersed having between 1 and less than 20 firms in any of the other ZC areas.

\section{Industrial Mix}

The differences in membership group composition are tested for the geographic subdivisions identified in the previous section in order to examine locational differences in the tourism business industry mix. The group composition of tourism businesses presented in Table 1 will be analyzed and compared for several geographic scales in a decreasing order: 1) State of Florida versus outof-state firms; 2) Orlando tri-county area (Orange, Osceola, and Seminole) versus rest of the State of Florida; 3 ) Theme park zone (TPZ) establishments versus the rest of Orlando tri-county area; and 4) TPZ versus the Orlando Central Business District (CBD). The differences found in tourism business composition between each pair of these regions are statistically examined using chi-square tests. The results are presented in Table 2.

Column A in Table 2 presents the results obtained for the difference in group composition between businesses located inside and outside the 


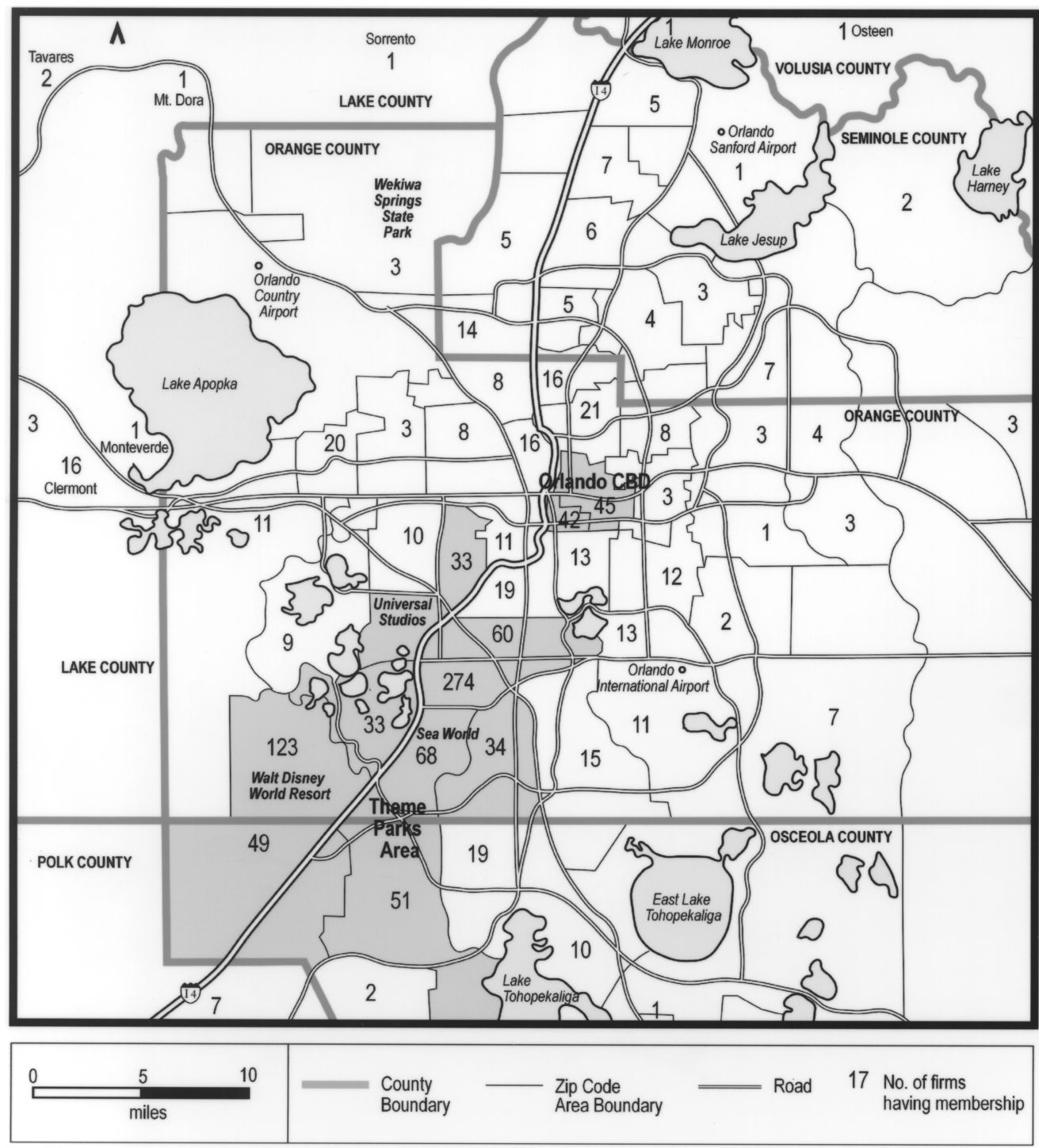

Figure 2. Number of firms having membership with the Orlando CVB by ZC areas.

State of Florida. Based on a chi-square test, the group composition or industrial mix of the out of state establishments is statistically significantly different from those found in the State of Florida. Out of state establishments are overrepresented by a high margin in convention services and transportation companies while they are underrepresented in the categories of dining, attraction, and to a lesser extent in accommodation.

Member firms located within the State of Flor- ida, inside and outside of the Orlando metro tricounty area, also exhibit statistically significant differences as presented in Column B of Table 2. Members located outside the tri-county boundaries tend to belong to the sectors of attractions and VPS in higher proportions and to dining with much lower proportion than those located inside the tri-county boundaries. The accommodation sector has a small edge inside the tri-county area. The test of these results remained significant $\left(\chi^{2}=\right.$ 
28.7, $p<0.01$ ) even when the sector of accommodation was omitted from the analysis. This last test was performed to make sure the results are not biased by the free enrollment advantage granted to Orange County accommodation establishments.

The results were double checked for a case where the tri-county boundaries were expanded to include the 44 firms located at a distance of less than 10 miles away from the external county lines (Fig. 1). The results shown in Table 2, column C indicate that those members located in the State of Florida remotely from Orlando tend to specialize in attractions, VPS, and to a lesser degree in convention services. Accommodation and dining firms are clearly less represented compared to their proportion among the local operators. These differences are statistically significant at the 0.01 level. The differences were still statistically significant $\left(\chi^{2}=25.796, p<0.01\right)$ even when the accommodation sector was omitted from the analysis.

Industrial mix examination on a finer geographic scale is made between those firms concentrated around the main theme parks in Orlando and those scattered elsewhere within the tri-county area, with and without its extension (Fig. 2, Table 2 , column D). The first group is composed of firms located in a zone that creates a cluster of nine $\mathrm{ZC}$ areas having 30 or more members in each ZC. This area is home to 713 firms, more than half of all firms associated with the OOCCVB.
This zone represents the highest concentration of tourism related firms in the Orlando region.

The figures in Table 2, column D show clearly that inside the theme park zone (TPZ) there is a tendency for a geographic alliance between accommodation and dining. These two sectors compose almost $60 \%$ of the membership within this heavily visited area. On the other hand, outside the TPZ the two business-to-business sectors of convention services and VPS have higher representation by wide margins. This area is also overrepresented, though by smaller margins, in the attractions and transportation sectors. It is interesting to note that no major differences have been identified regarding the location of members representing the attraction businesses in and outside of the theme park zone: $14.6 \%$ in the area outside of the theme park zone and $11.8 \%$ in the theme park zone. However, differences in sizes between those in and out of the theme park zone should be expected, with bigger attractions being more likely found in the theme park zone. The TPZ composition of firms was further tested vis-à-vis the rest of the firms located in the extended tri-county areas (Table 2, column D). The results are nearly similar to those obtained for the limited tri-county boundaries without major differences.

One final geostatistical examination is carried out intending to distinguish between membership composition in the TPZ and the Orlando CBD

Table 2

Comparison of Tourism Businesses Based on Geographic Locations

\begin{tabular}{|c|c|c|c|c|c|c|c|c|c|c|c|}
\hline \multirow[b]{2}{*}{ Type of Business } & \multicolumn{2}{|c|}{ A: Florida } & \multicolumn{2}{|c|}{ B: Tr-County } & \multicolumn{2}{|c|}{$\begin{array}{l}\text { C: Extended } \\
\text { Tri-County }\end{array}$} & \multicolumn{3}{|c|}{$\begin{array}{c}\text { D: Theme } \\
\text { Park Zone (TPZ) }\end{array}$} & \multicolumn{2}{|c|}{ E: TPZ vs. CBD } \\
\hline & $\%$ In & $\%$ Out & $\%$ In & $\%$ Out & $\%$ In & $\%$ Out & $\%$ In & $\%$ Out $^{\mathrm{a}}$ & $\%$ Out $^{\mathrm{b}}$ & $\%$ In & $\%$ Out \\
\hline Accommodation & 23.8 & 17.3 & 24.1 & 21.4 & 24.9 & 5.5 & 31.7 & 11.9 & 15.1 & 31.7 & 8.0 \\
\hline Convention services & 20.7 & 37.3 & 20.8 & 19.7 & 20.6 & 23.3 & 14.6 & 30.8 & 39.2 & 14.6 & 29.9 \\
\hline Dining & 18.7 & 8.0 & 20.0 & 6.0 & 19.5 & 4.1 & 26.9 & 8.8 & 8.8 & 26.9 & 11.5 \\
\hline Visitor \& professional services & 14.7 & 16.0 & 14.2 & 19.7 & 14.0 & 26.0 & 8.8 & 22.7 & 21.5 & 8.8 & 27.6 \\
\hline Attractions & 14.2 & 4.0 & 12.9 & 27.3 & 13.1 & 32.9 & 11.8 & 14.6 & 14.9 & 11.8 & 18.4 \\
\hline Retail & 4.4 & 6.7 & 4.5 & 3.4 & 4.4 & 4.1 & 4.2 & 4.9 & 4.7 & 4.2 & 3.4 \\
\hline Transportation & 3.5 & 10.7 & 3.6 & 2.6 & 3.5 & 4.1 & 2.0 & 6.3 & 5.7 & 2.0 & 1.1 \\
\hline Total number & 1,275 & 75 & 1,158 & 117 & 1,202 & 73 & 713 & 445 & 489 & 713 & 87 \\
\hline Statistical test $(d f=6)$ & \multicolumn{2}{|c|}{$\begin{array}{c}\chi^{2}=30.28 \\
p<0.01\end{array}$} & \multicolumn{2}{|c|}{$\begin{array}{c}\chi^{2}=30.01 \\
p<0.01\end{array}$} & \multicolumn{2}{|c|}{$\begin{array}{c}\chi^{2}=45.93 \\
p<0.01\end{array}$} & \multicolumn{3}{|c|}{$\begin{array}{c}\chi^{2}=158.26 / 177.75 \\
p<0.01\end{array}$} & \multicolumn{2}{|c|}{$\begin{array}{c}\chi^{2}=61.53 \\
p<0.01\end{array}$} \\
\hline
\end{tabular}

${ }^{a}$ Tri-county out of theme park zone.

${ }^{\mathrm{b}}$ Extended tri-county out of theme park zone. 
area. While the former zone has an expansive aerial dimension composed of nine $\mathrm{ZC}$ areas, the latter is a small geographic unit consists of two small $\mathrm{ZC}$ areas containing 87 tourism-related firms. The results presented in Table 2, column E seem to indicate that these two zones differ greatly in their membership composition. While the TPZ is highly represented by accommodation and dining, the CBD area is rather loaded with convention services and VPS. Here again, percentage wise, the $\mathrm{CBD}$ area has higher representation of attractions than the theme parks' area.

It is interesting to note that members representing the attraction sector are constantly less represented inside the Orlando tri-county area and inside of the TPZ as opposed to outside of these areas. Although this sector provides the raisond'être for the region's tourism industry-representing the nucleus in Gunn's (1988) terminology - the lower representation of attractions inside these areas reflects the difference in size of the attractions between those in and out of the Orlando area in general and the TPZ in particular. In a nutshell, in the TPZ and inside the tri-county area, small proportion of large size attractions is accompanied by high proportion of accommodation and dining services, while outside of the TPZ more attractions of smaller size are neighbors to a high proportion of tourism business services.

\section{Conclusion, Implications, and Direction for Future Research}

The results of the study have revealed that even in a world class mega-destination such as Orlando, tourism firms tend to be agglomerated in a relatively small geographic area. Nearly $90 \%$ of the firms are located within the Orlando tri-county boundaries. Although the OOCCVB accept memberships regardless of geographic or administrative affiliation, a clear-cut destination area is forged out extending to a maximum of 10 miles away from the Orlando tri-county area. The study further revealed that tourism firms tend to be agglomerated in a relatively small geographic area. More than half of the firms registered as members in the OOCCVB are located in and next to the main theme parks area. This is a geographic area larger than the usual tourism bubble ascribed to other Western cities. Yet, it is still an area where tourists are most likely to intermingle with other tourists. This large concentration of tourists and tourism firms is supposed to generate externalities gained via agglomeration economies. Nevertheless, tourism firms prevail in lower densities even outside of the theme parks area throughout the Orlando destination region. It will be safe to conclude that if such a concentrated pattern prevails in a mega-destination such as Orlando, smaller size tourism destinations would probably exhibit even more concentrated agglomerations.

Group composition, or industrial mix, was shown to vary depending on geographic location. On the one hand, the core of the theme parks region is disproportionately represented by accommodation and dining firms. These are typical business-tocustomer services. On the other hand, external zones, including the Orlando CBD, are highly represented by business-to-business service providers such as convention services and VPS. Smaller scale attractions and transportation businesses also show a tendency to locate outside of the core region.

These results are well embedded within several realms of the social sciences. From a sociological point of view, the results seem to support the tourist bubble perception (Judd, 1999; Urry, 1990), though not without reservations. The Orlando TPZ is spread over a large territorial space occupying much of the southwest quarter of Metropolitan Orlando. In this respect it is far from being a typical Western world tourist bubble squeezed into a promenade, water front, or pedestrian shopping street-attributes amply supplied within the theme parks themselves. Although geographically much larger than the tourist bubbles perceived in the literature, operationally it can still be regarded as a bubble-like tourist area encompassing the theme parks and their surrounding area, interlaced with a few transport arteries (I-4, International Drive, Universal Boulevard, and US 192) as their main backbone. Although certain sections of this area may include nontourism businesses, its focal points constitute places where tourists are most likely to meet other tourists not only at their hotels, restaurants, and attractions, but also at shopping malls and numerous outlet stores. It is an area wherein tourists are circulated by shuttle buses to 
and from hotels, attractions, dining places, and outlet centers. This may be regarded as a typical "tourist activity space" of the type envisaged by Jansen-Verbeke and Lievois (1999, 2004). From a marketing viewpoint, this area represents a culture of tourism, yet with less resentment than that reported for such exotic places as Bali (Minca, 2000), probably due to a lesser deviation between perception and reality (Murphy, Pritchard, \& Smith, 2000; Sachez, Callarisa, Rodriguez, \& Moliner, 2006).

In the field of economic geography, such a geographic situation represents a place where firms and individuals may reap the benefits of agglomeration economies (Ioannides, 1995). Firms benefit from the large market, availability of professional services, first hand knowledge of innovations, flow of information, and convenient opportunities for face-to-face contacts. Much of these externalities are provided through membership in the local CVB organization. The tourists benefit from the diverse and large selection of attractions, dining places, and accommodation, convenient internal transportation, bargain tickets offered due to fierce competition, and the special atmosphere of fun and relaxation (Bigne, Andreu, \& Gnoth, 2005).

From a management perspective, the spatial dimension of tourism organizations identified in the study is also a reflection of the networking approach to the development of tourist destinations (Grangsjo, 2003). Previous studies have shown the advantages of destination development by involving various sectors of the tourism industry for the total offering of the tourism products (JansenVerbeke \& Lievois, 2004; Parmer \& Bejou, 1995; Weaver \& Oppermann, 2000). The clustering of these tourism organizations not only contributes to the holistic travel experience for visitors, but also gives the place its special atmosphere and character (Buhalis \& Cooper, 1998). To a great extent, the combination and networking of tourism organizations is an essential part of a tourist destination as it is one of the motivating factors behind the tourist's decision and expectations. In this process, the dynamics of the destination composition evolve, which steers the process of change that form and shape the spatial characteristics of the destination.

From a tourism planning viewpoint, the ex- tended Orlando tri-county area should be viewed as a destination region characterized by three zones being in partial agreement with Gunn's perception (1988, 2002). The theme park bubble-like area constitutes the nucleus or the busy network of "tourist activity space" (Jansen-Verbeke \& Lievois, 1999, 2004). The rest of the metro area represents the second zone. It offers additional accommodation and attractions, yet it is disproportionately loaded with tourism business services. The third zone is the area outside the metro boundaries. Although this area also offers tourism attractions and accommodations, only few firms located in this zone consider an alliance with the nucleus DMO organization as an advantageous and profitable business opportunity.

In Gunn's $(1988,2002)$ view the metropolis is considered as a buffer zone a visitor must pass so as to reach the attraction at the nucleus. Metropolitan Orlando appears to offer to the tourists much more than a meaningless buffer zone to be traversed on the way to the nuclei. First, this zone with its scattered tourism firms serves as a spillover area accommodating tourists, especially at times of peaking demand. These tourism firms offer additional, though usually less lucrative, attractions and accommodations. Second, this zone, including the Orlando CBD area, houses many of the tourism industry service providers. This zone provides the professional services and transport solutions that attract and accommodate the annual 40 million plus visitors. Third, this zone supplies the environs for housing, education, social encounters, and livelihood for most of the 206,500 employees working directly in the Orlando tourism sector (Orlando CVB, 2005). These are the people who then cater for the tourists.

To a large extent, the dependence of the city on tourism employment, the overwhelming dominance of the tourism industry over the entire metropolitan space, and the separation of the bubblelike theme park zone from the rest of the city may explain the minimal level of antagonism developed against the tourism industry from the side of the city's residents (Sheldon \& Abenoja, 2001). Under such circumstances, tourism probably becomes an integral part of Orlando residents' place identity (Christenson, 1993).

Despite this neat structure of the three zones, 
one may still deliberate the question of whether the extended Orlando tri-county area as delineated in this study can be separated from the rest of central Florida. It is only about 1-hour drive before tourists may reach other significant tourism destinations such as Kennedy Space Center at Cape Canaveral to the east, Daytona Beach, and St. Augustine to the north, or Tampa and Lakeland resort area to the south. Nevertheless, the intensity of the OOCCVB-oriented tourism businesses tapers off to one or zero firms in each $\mathrm{ZC}$ area before reaching these destinations. The relationships of the Orlando destination region with the other surrounding destinations may, perhaps, be conceptualized in the form of a "chained destination region" portrayed by Dredge (1999, p. 785).

Finally, it is appropriate to discuss the specific nature of the database used for this study. Firms having membership with the OOCCVB could have come from a widely dispersed geographic area had they anticipated having benefits from the information circulated by this organization. It turned out, contrary to this option, that almost all firms are locally oriented, constituting a clear-cut destination region. This does not mean that there are no tourism firms located on the outskirt of this region that do not have membership with the OOCCVB. Just the opposite is the case. For instance, the southerly neighboring Kissimmee-St. Cloud CVB, the second largest promotional organization in the region with 60 employees, has a policy of free membership to all tourism businesses located in Osceola County. Nevertheless, there are many businesses in this county whose best interest guides them to having an additional paid membership with the OOCCVB as well. However, almost all these businesses are located near the southern boundary of Orange County, emphasizing the geographically confined nature of the Orlando tourism destination region.

Further research is due on the rivalry situation vis-à-vis potential benefits that may accrue from cross-boundary cooperation between the two neighboring CVBs. Research on cross-boundary benefits and obstacles has been now under way for years by Timothy (2001). A current contribution has been published recently by Ioannides, Nielsen, and Billing (2006), referring to the case of the Bothnian Arc shared by Finland and Sweden.
However, these studies deal mainly with issues pertaining to ventures taking place across national boundaries. Studies dealing with cross-jurisdictional cooperation are rather rare, Greer (2002) being an exception.

The research on the territorial and industrial structure of destination regions appears to be in its initial stage. More studies should aim at comprehending the overall distribution of tourism firms within destination regions. Finer geographic scale studies may be conducted to investigate the impact of zoning regulations; and more in-depth studies are necessary to understand the benefits accrued to tourism firms due to their geographic agglomeration. Identification and delineation of destination regions has a multitude of implications not only for destination marketing but also for destination planning and management. Most people tend to work, live, and act in mentally bounded territories. Constituencies of bounded territories, such as cities and counties, share political, educational, and cultural institutions; they are exposed to same media coverage, and pay local taxes. Such localized attributes help generate a sense of place and make people acquire place identity and sentiment (Christenson, 1993). Arrival of tourists to destinations has a significant impact on place identity. Being a partner in the host-guest contact process, tourists are known to provoke community reactions on a scale from euphoria to antagonism (Doxey, 1976; Lindberg \& Johnson, 1997). However, community reaction is probably affected, among other things, by destination areas delineation, and by tourist volumes and circulation. The impact of large numbers of tourists thinly dispersed over a sizable destination area would be quite different than that of same numbers squeezed into a small geographic unit. No doubt, further studies are needed to investigate the impact of the size effect of tourism destinations, their internal dispersion, and the spread of tourists therein on destination planning and management-related issues.

\section{References}

Augustyn, M., \& Knowles, T. (2000). Performance of tourism partnerships: A focus on York. Tourism Management, 21, 341-351.

Benedetto, C. A., \& Bojanic, D. C. (1993). Tourism area 
life cycle extensions. Annals of Tourism Research, 20, 557-570.

Bigne, J. E., Andreu, L., \& Gnoth, J. (2005). The theme park experience: An analysis of pleasure, arousal, and satisfaction. Tourism Management, 26, 833-844.

Bramwell, B., \& Rawding, L. (1994). Tourism marketing organizations in industrial cities: Organizations, objectives, and urban governance. Tourism Management, 15, 425-435.

Buhalis, D., \& Cooper, C. (1998). Competition or cooperation? Small and medium sized tourism enterprises at the destination. In E. Laws, B. Faulkner, \& G. Moscardo (Eds.), Embracing and managing change in tourism: International case studies (pp. 324-346). London: Routledge.

Butler, R. W. (1980). The concept of a tourist area cycle of evolution. Canadian Geographers, 24, 5-12.

Butler, R. W. (2006). The tourism area life cycle. Clevedon: Channel View Publication.

Christaller, W. (1966). Central places in southern Germany (C. W. Baskin, Trans.). Englewood Cliffs, N.J.: Prentice-Hall. (Original work published 1933)

Christenson, J. A. (1993). Urbanism and community sentiment: Extending Wirth's model. In M. Baldassare (Ed.), Cities and urban living (pp. 181-196). New York: Columbia University Press.

Dredge, D. (1999). Destination place planning and design. Annals of Tourism Research, 26, 772-791.

Douglas, N. (1997). Applying the life cycle model to Melanesia. Annals of Tourism Research, 24, 1-22.

Doxey, G. V. (1976). When enough's enough: The natives are restless in old town Niagara. Heritage Canada, 2, 26-29.

Fagence, M. (1991). Geographic referencing of public policies in tourism. The Tourist Review, 3, 8-19.

Fyall, A., \& Garrod, B. (2004). Tourism marketing: A collaborative approach. Clevedon: Channel View Publications.

Foglesong, R. (1999). Walt Disney World and Orlando deregulation as a strategy for tourism. In D. R. Gudd \& S. S. Fainstein (Eds.), The tourist city (pp. 89-106). New Haven, CT: Yale University Press.

Gartrell, R. B. (1992). Convention and visitor bureaus: Current issues in management and marketing. Journal of Travel and Tourism Marketing, 1, 71-78.

Getz, D. (1986). Models in tourism planning: Towards the integration of theory and practice. Tourism Management, 7, 21-32.

Getz, D., Anderson, D., \& Sheehan, L. (1998). Roles, issues, and strategies for convention and visitors bureaus in destination planning and product development: A survey of Canadian bureaus. Tourism Management, 19, 331-340.

Gradus, Y., \& Stern, E. (1980). Changing strategies of development: Toward a regiopolis in the Negev Desert. Journal of the American Planners Association, 46, 410-423.

Grangsjo, Y. (2003). Destination networking: Co-opetition in peripheral surroundings. International Journal of Physical Distribution \& Logistics Management, 33(5), 427-448

Greer, J. (2002). Developing trans-jurisdictional tourism partnerships-insights from the Island of Ireland. Tourism Management, 23, 355-366.

Gunn, C. A. (1988). Vacationspace: Designing tourist regions. New York: Van Nostrand Reinhold Company.

Gunn, C. A., \& Var, T. (2002). Tourism planning. New York: Taylor and Francis.

Heath, E., \& Wall, G. (1992). Marketing tourism destinations: A strategic planning approach. New York: John Wiley \& Sons.

Hudman, L. E., \& Jackson, R. H. (2003). Geography of travel and tourism (4th edition). Australia: Thomson Delmar Learning.

Inskeep, B. (1991). Tourism planning: An integrated and sustainable development approach. New York: Van Nostrand Reinhold.

Ioannides, D. (1995). Strengthening the ties between tourism and economic geography: A theoretical agenda. Professional Geographer, 47, 49-60.

Ioannides, D., Nielsen, P., \& Billing, P. (2006). Transboundary collaboration in tourism: The case of the Bothnian Arc. Tourism Geographies, 8, 122-142.

Jansen-Verbeke, M. (1992). Urban recreation and tourism: Physical planning issues. Tourism Recreation Review, 17, 33-45.

Jansen-Verbeke, M., \& Lievois, E. (1999). Analyzing heritage resources for urban tourism in European cities. In D. G. Pearce \& R. W. Butler (Eds.), Contemporary issues in tourism development (pp. 81-107). London: Routledge.

Jansen-Verbeke, M., \& Lievois, E. (2004). Urban tourismscapes: Research-based destination management. In K. A. Smith \& C. Schott (Eds.), Proceedings of the New Zealand Tourism and Hospitality Research Conference (pp. 170-179), Wellington, December 8-10.

Judd, D. R. (1999). Constructing the tourist bubble. In D. R. Judd \& S. S. Fainstein (Eds.), The tourist city (pp. 35-53). New Haven, CT: Yale University Press.

Karplus, Y., \& Krakover, S. (2004). Stochastic multi-variable approach to modeling tourism area life cycles. Tourism and Hospitality Research, 5, 235-253.

Krugman, P. R. (1998). Development, geography, and economic development. Cambridge: MIT Press.

Laws, E. (1995). Tourism destination management: Issues, analysis, and policies. New York: Rutledge.

Lindberg, K., \& Johnson, R. (1997). Modeling resident attitudes toward tourism. Annals of Tourism Research, 24, 402-424.

McCann, P., \& Shefer, D. (2005). Agglomeration, economic geography, and regional growth. Papers in Regional Science, 84, 301-309.

Migdal, D. (1993). Getting the best from your bureau. Meetings and Conventions, 28, 51-70.

Minca, C. (2000). The Bali syndrome: The explosion and 
implosion of 'exotic' tourist spaces. Tourism Geographies, 2, 389-403.

Morrison, A. M., Bruen, S. M., \& Anderson, D.J. (1998). Convention and visitor bureaus in the USA: A profile of bureaus, bureau Executives, and budgets. Journal of Travel and Tourism Marketing, 7, 1-19.

Murphy, P. E., Pritchard, M., \& Smith, B. (2000). The destination product and its impact on traveler perceptions. Tourism Management, 21, 43-52.

Myung, SeJung, $\bullet$ Morrison, A. M., \& $\bullet$ Taylor, J. S. (2005). The effectiveness of convention and exhibition websites: A transatlantic comparison and future scenario. Tourism Recreation Research, 30, 49-59.

Orlando CVB. (2005). Annual research report. Orlando: Author.

Ovechka, G. (1993, October). Partners in marketing. How convention and visitor bureaus can make a hotelier's day. Lodging, 46-51.

Palmer, A., \& Bejou, D. (1995). Tourism destination marketing alliances. Annals of Tourism Research, 22, 616629.

Papatheodorou, A. (2004). Exploring the evolution of tourism resorts. Annals of Tourism Research, 31, 219-237.

Pearce, D. (1995). Tourism today: A geographical analysis (2nd ed.). New York: Longman.

Presenza, A., Sheehan, L., \& Ritchie, J. R. B. (2005). To- wards a model of the roles and activities of destination management organizations. Journal of Hospitality, Tourism, \& Leisure Science, 3, 1-16.

Sachez, J., Callarisa, L., Rodriguez, R. M., \& Moliner, M. A. (2006). Perceived value of the purchase of a tourism product. $\cdot$ Tourism Management, 27, 394-409.

Sautter, E. T., \& Leisen, B. (1999). Managing stakeholders: A tourism planning model. Annals of Tourism Research, 26, 312-328.

Sheldon, P. J., \& Abenoja, T. (2001). Resident attitudes in a mature destination: The case of Waikiki. Tourism Management, 22, 435-443.

Timothy, D. J. (2001). Tourism and political boundaries. London: Routledge Advances in Tourism.

Urry, J. (1990). The tourist gaze. London: Sage Publication. von Thunen, J. H. (1966). Isolated state (C. M. Wartenberg, Trans., P. Hall, Ed.) Oxford/New York: Pergamon Press. (Original worrk Der isolierte Staat published 1826)

Weaver, D., \& Oppermann, M. (2000). Tourism management. Milton: Wiley.

Weber, K. (2001). Meeting planners' use and evaluation of convention and visitor bureaus. $\cdot$ Tourism Management, 22, 599-606.

World Tourism Organization. (2004). Survey of destination management organizations. Madrid, Spain: Author. 